\title{
Effect of methyl jasmonate, salicylic acid and ascorbic acid on quality parameters of strawberry (Fragaria $x$ ananassa Duch) fruit during cold storage
}

\author{
Merab Jgenti, Levan Gulua, Tamar Turmanidze
}

Agricultural University of Georgia, Tbilisi, Georgia

\section{Keywords:}

Strawberry

Phenolic

Antioxidant

Anthocyanins

Methyl jasmonate

Salicylic acid,

Ascorbic acid

\section{Article history:}

Received

10.08.2018

Received in

revised form

30.08.2018

Accepted

28.09.2018

Corresponding

author:

Tamar Turmanidze

E-mail:

tturm2010@

agruni.edu.ge

DOI:

$10.24263 / 2304-$

974X-2018-7-3-3

\section{Abstract}

Introduction. The objective of this work was to investigate the combined solution effects of methyl jasmonate, salicylic acid and ascorbic acid on storability of strawberry fruits.

Materials and methods. The anthocyanins were quantified by the $\mathrm{pH}$ differential method. Total phenolic compounds were determined by method using Folin-Ciocalteau reagent. FRAP assay was applied in order to determine antioxidant activity. Determination of individual anthocyanins by HPLC was performed by a Varian- Prostar-500 series liquid chromatograph. The texture analyses of the strawberries were carried out using a Texture Analyser.

Results and discussion. Effect of combined solution of Methyl jasmonate (MJ), Salicylic acid (SA) and Ascorbic acid (AA) on storability of strawberry fruits (Victoria and Camarosa varieties) was investigated. Treatment with $\mathrm{MJ}, \mathrm{SA}$ and $\mathrm{AA}$ positively influenced on the level of content of vitamin $\mathrm{C}$ in strawberries fruits during storage.Total anthocyanins in the control samples of Victoria gradually decreased from $21.35 \pm 1.06$ to $13.35 \pm 0.66 \mathrm{mg} 100 \mathrm{~g}^{-1}$ on the 13-th day of storage. As to the treated samples, anthocyanins content reduced to $15.49 \pm 0.77 \mathrm{mg} 100 \mathrm{~g}^{-1}$. In the samples of Camarosa total anthocyanins reduced from $46.93 \pm 2.34$ to $20.41 \pm 1.02$ and to $34.59 \pm 1.72 \mathrm{mg}$ per $100 \mathrm{~g}$ fruits in control and treated samples respectively.Total phenolic compounds (TPC) in the control samples of Victoria initially was equal to $129.86 \pm 6.49 \mathrm{mglO}^{-1}$ and at the end of experiment, it reduced to $111.15 \pm 5.55 \mathrm{mg} 100 \mathrm{~g}^{-1}$. Whereas, in the treated sample TPC was unchanged. TPC in Camarosa initially was by $40 \%$ more

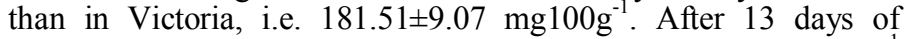
storage, TPC reduced to $131.00 \pm 6.55$ and to $150.02 \pm 7.50 \mathrm{mg}^{100 \mathrm{~g}^{-1}}$ in the control and treated samples respectively. Effect of treatment was statistically and practically significant. During storage period, antioxidant activity of the fruits decreased gradually. Change in antioxidant activity of the treated samples was less significant than in untreated sample. i.e by 17.9 and $23.3 \%$ for the fruits of Victoria and Camarosa varieties respectively. Main anthocyanin in the fruits of both varieties was Pelargonidin-3-O-glucoside. Its initial content in the fruits was $68.45 \pm 3.42$ and $65.28 \pm 3.26 \%$ of total anthocyanins for Victoria and Camarosa varieties respectively.

Conclusion Treatment of fruits of strawberry with combined solutions of methyl jasmonate, salicylic acid and ascorbic acid positively influenced on storability of the fruits. Maintenance of anthocyanins and total phenolics as well as antioxidant potential during storage period was statistically significantly increased. Treatment with combined solution resulted in improvement of texture of fruits during storage process. 


\section{Introduction}

Strawberries (Fragaria $\mathrm{x}$ ananassa Duch) are one of the most popular berries in the world. The quality, chemical composition and sensory parameters of strawberries during fresh storage period have been studied intensively [1]. Strawberries are a good source of vitamins and minerals, and their quality and chemical composition vary among cultivars and with postharvest handling conditions [2]. Also, strawberry fruit is a rich source of natural antioxidants and phytochemicals, particularly anthocyanins, flavonoids, phenolic acids[3-8]. However, shelf life of strawberries is very limited. During fresh storage fruits undergo significant microbial decay, fruit softening, water loss, loss of red color, brown pigment formation, and flavor changes [1,9-10].

Various chemical compounds have been used to treat the strawberry fruits in order to reduce such undesirable changes during storage period and to prolong shelf life of the fruits.

MJ and SA are endogenous plant hormones that play principal roles in regulating stress responses and plant development [11-12].

Methyl jasmonate (MJ)is a plant growth regulator and it very actively participates in many physiological processes $[12,13]$. MJ serves as a signal molecule to initiate the defense mechanism in response to stress conditions [14]. According to Cardemil and coauthors, post-harvest treatments of fruits with jasmonate stimulates the production of such antioxidants as flavonoids, anthocyanins, phenolic acids; improvesthe fruits quality and prolongs their shelf life [15].

Salicylic acid (SA) is a hormonal substance, participating in regulation of numerous physiological processes [16]. SA can inhibit biosynthesis of ethylene in fruits and in such a way delay the ripening of fruits. SA reduces fruit deterioration caused by chill injury and fungal disease during fresh storage period[17].

Ascorbic acid (AA) is known to inhibit browning process in fruits. In addition, AA is cheap and safe for human consumption [18, 19-24].

The objective of our work was to investigate the combined solution effects of methyl jasmonate, salicylic acid and ascorbic acid on storability of strawberry fruits.

\section{Material and methods}

\subsection{Chemicals}

Ascorbic acid higher than $99.0 \%$ and potassium dihydrogen phosphate were purchased from Sigma-Aldrich (Steinheim, Germany); TPTZ - 2-4-6-tris (2-pyridyl)-s-triazine (Sigma-Aldrich, Switzerland), the Folin-Ciocalteau reagent (Appli Chem, Germany), hydrochloric acid, formic acid and phosphoric acid were provided by Merck (Darm-stadt, Germany); sodium carbonate was purchased from ChemCruz (ChemCruz Biochemicals, USA); ethyl acetate and methanol (Sigma-Aldrich, Steinheim, Germany) were HPLC grade. All other reagents were commercially available at the local market and were of analytical grade.

\subsection{Sample collection}

The strawberries (Camarosa and Victoria) were harvested in mid-summer in the eastern part of Georgia (GPS coordinates: Latitude: 4157'59.99” N, Longitude: 4405'60.00” E). After harvesting, representative samples of the fruits were treated with combined solution $(0.005 \% \mathrm{MJ}, 0.15 \% \mathrm{SA}, 1 \% \mathrm{AA})$ at $20 \pm 1{ }^{\circ} \mathrm{C}$ with an exposure time of $2.0 \mathrm{~min}$. The treated 
samples were stored in a refrigerator at $0 \pm 0.5{ }^{\circ} \mathrm{C}$ and $95 \pm 0.5 \%$ RH. Quality parameters such as vitamin $\mathrm{C}$ content, TPC and anthocyanin content, as well as the antioxidant potential were monitored at the start of sampling and after 4,7,10 and 13 days.

\subsection{Sampling procedure}

The samples were prepared for the ascorbic acid determination by HPLC (VarianProstar-500, USA, detector-UV varian Prostar, Australia, column- $250 \mathrm{~mm} \times 4.6 \mathrm{~mm}, \mathrm{dp}=$ $5 \mu \mathrm{m}$ (Symmetry, Waters, Ireland) [25] as follows: briefly, the sample (10 g) was extracted in $10 \mathrm{~mL}$ water adjusted to $\mathrm{pH} 1.5$ with $10 \mathrm{~mL}$ phosphoric acid-water $(2 \%, \mathrm{v} / \mathrm{v})$. The extracts were filtered through $45 \mu \mathrm{m}$ filter paper (Whatman, UK) and $1.5 \mathrm{~mL}$ buffer $(0.01$ $\mathrm{M} \mathrm{KH} 2 \mathrm{PO} 4, \mathrm{pH} 8.0$ ) then added to $1.5 \mathrm{~mL}$ of the sample extract. $1 \mathrm{~mL}$ aliquots (vitamin C) of each of the preferred mixtures were then loaded on to $\mathrm{C} 18$ cartridges (Agilent, Bond Elut, USA) and $3 \mathrm{~mL}$ aliquots of water adjusted to $\mathrm{pH} 1.5$ with $2 \mathrm{~mL}$ phosphoric acid-water $(2 \%, v / v)$ passed through them.

The samples used for the antioxidant analysis were prepared according to RodriguezSaona and Wrolstad (2001) [26]. About $40 \mathrm{~g}$ of strawberries was cryogenically milled in liquid nitrogen. Chilled test tubes were filled with milled fruit powder and weighed $(5 \mathrm{~g})$, and the powder then extracted with acetone $(200 \mathrm{~mL})$.The acetone was removed under vacuum in a rotary evaporator at $<30^{\circ} \mathrm{C}$, and $250 \mathrm{~mL}$ of methanol $(70 \%)$ then added to the powder. The total methanol extract was examined for antioxidant activity.

Samples for anthocyanin analyses by High performance liquid chromatography, HPLC (Varian - Prostar - 500, USA, detector - UV varian Prostar, Australia, column - S $250 \mathrm{x}$ 4.6, Agilent, Microsorb - 100 - 5, The Netherlands) were prepared according to Prior et al. (2012) [27]. Berries ( $40 \mathrm{~g}$ ) were homogenized in methanol/water/formic acid in a ratio of 60: 37: $3(\mathrm{v} / \mathrm{v} / \mathrm{v})$, kept overnight $(14 \mathrm{~h})$ at $3-5^{\circ} \mathrm{C}$ and later filtered by filter $45 \mu \mathrm{m}$ (Whatman, UK) through a Buchner funnel under vacuum. The filtrates were centrifuged $\left(4000 \mathrm{X} \mathrm{g}, 15 \mathrm{~min}, 21^{\circ} \mathrm{C}\right)$ The supernatant was concentrated under vacuum in a rotary evaporator at $<30^{\circ} \mathrm{C}$ to total evaporation of the methanol. An aliquot $(2.0 \mathrm{~mL})$ of the aqueous phase was carefully deposited onto a C - 18 cartridge (Agilent, Bond Elut, USA). sugars and more polar substances were removed by passing $2.0 \mathrm{~mL}$ of ultrapure water through the cartridge. polyphenols were removed by passing $2.0 \mathrm{~mL}$ of ethyl acetate and finally anthocyanin pigments were eluted with $10 \mathrm{~mL}$ of methanol. $10 \mathrm{~mL}$ deionized (DI) water was added to the methanol extract and then the methanol was removed under vacuum in a rotary evaporator at $<30^{\circ} \mathrm{C}$.

\subsection{Determination of $\mathrm{pH}$} [28].

$\mathrm{pH}$ value of the berry fruits was measured using a pH-meter (EHS-320, China) at $20^{\circ} \mathrm{C}$

\subsection{Determination of vitamin $C$}

Vitamin C was determined by the HPLC method [25]. The columns used were $250 \mathrm{~mm}$ $\times 4.6 \mathrm{~mm}, \mathrm{dp}=5 \mu \mathrm{m}$ (Symmetry, Waters, Ireland) and the mobile phase was water adjusted to $\mathrm{pH} 3$ with phosphoric acid. The UV detector (Varian pro Star, Australia) was set at 215 $\mathrm{nm}$ and quantification was based on the peak area measurement. For HPLC (Varian-Prostar-500, USA), $20 \mu \mathrm{L}$ of sample were injected.

\subsection{Determination of total Anthocyanins}

The anthocyanins were quantified by the $\mathrm{pH}$ differential method [29]. Samples were diluted 1:150 in $\mathrm{pH} 1.0$ and $\mathrm{pH} 4.5$ buffers, and the absorbance measured at $520 \mathrm{~nm}$ and $700 \mathrm{~nm}$ in a UV -Visible spectrophotometer (A \& E Lab Co LTD, UK), based on a 
cyanidin 3-glucoside molar extinction coefficient of 26,900 $\Delta \mathrm{Emol}^{-1}$ and a molecular weight of $449.2 \mathrm{gmol}^{-1}$. The resulting values were expressed in terms of $\mathrm{mg}$ of anthocyanin per $100 \mathrm{~g}$ of fresh fruit.

\subsection{Determination TPC}

TPC was performed by Bond et al. (2003) [30]. As aliquot of $1.0 \mathrm{~mL}$ of diluted sample extract was vortexed with $10 \mathrm{~mL}$ DI water and $1.0 \mathrm{~mL}$ Folin-Ciocalteau reagent, and a 1.0 $\mathrm{mL}$ deionized water was used as control. After equilibration at room temperature for $8 \mathrm{~min}$, the solutions were mixed with $4 \mathrm{~mL}$ of $7.5 \%(\mathrm{w} / \mathrm{v}) \mathrm{Na}_{2} \mathrm{CO}_{3}$. The samples and standards (Gallic acid dilute working standard solutions: $10-50 \mu \mathrm{gmL}^{-1}$ ) were equilibrated at room temperature for 60 minutes. The absorbance of the samples and standards were measured spectrophotometrically (UV/Vis spectrophotometer, A\&E Lab Co LTD, UK) at $765 \mathrm{~nm}$, with a $10 \mathrm{~mm}$ path length cell. TPC was calculated as $\mathrm{mg}$ of gallic acid equivalents per 100 $\mathrm{g}$ fresh weight of sample.

\subsection{Determination of individual anthocyanins by HPLC}

Determination of Anthocyanins by HPLC Analyses was performed by a Varian Prostar - 500 series liquid chromatograph. Separation was achieved on a C18, $150 \mathrm{~mm} \times$ $4.6 \mathrm{~mm}$ column. Solvents used were: (A) Aqueous Trifluoroacetic acid (TFA) $0.1 \%$, and (B) Methanol 100\%, establishing the following gradient: isocratic $6 \% \mathrm{~B}$ for $5 \mathrm{~min}, 30 \% \mathrm{~B}$ over $10 \mathrm{~min}$, isocratic $50 \% \mathrm{~B}$ for $15 \mathrm{~min}, 60 \% \mathrm{~B}$ over $5 \mathrm{~min}$, and $6 \% \mathrm{~B}$ over $10 \mathrm{~min}$, using a flow rate of $0.4 \mathrm{~mL}$ min-1, using $518 \mathrm{~nm}$ wavelength, and a mass spectrometer (MS, Varian-prostar-500, USA) connected to the HPLC system. The Mass Spectrometer (MS) was equipped with an Electro Spray Ionization (ESI) source and an ion trap mass analyzer. Spectra were recorded in positive ion mode 3500 volts. Quantification of anthocyanins content was carried out according to chromatographic peaks at $518 \mathrm{~nm}$ wavelength.

\subsection{FRAP assay}

The Ferric Reducing Ability of Plasma (FRAP) assay was carried out as previously described by Benzie and Strain (1996) [31]. The experiment was carried out at $37^{\circ} \mathrm{C}$ and pH 3.6 with a blank sample in parallel. In the FRAP assay, the reductants ("antioxidants") in the sample reduce the $\mathrm{Fe}$ (III)/tripyridyltriazine complex to the blue ferrous form, with an increase in absorbance at $593 \mathrm{~nm}$. The final results were expressed as micromole AA equivalents per 100 gram (mmol AA100g $\left.\mathrm{g}^{-1}\right)$.

\subsection{Texture Profile Analysis (TPA)}

The texture analyses of the strawberries were carried out using a Texture Analyser (LLOYD, TA1, AMETEK Inc, USA).Cylindrical probe with $10 \mathrm{~mm}$ diameter was applied. Extension speed of the probe was $100 \mathrm{mmmin}^{-1}$. Work done by probe, which caused the sample to rupture, was calculated.

\subsection{Statistical Analysis}

The data represents the mean of three replicates \pm standard deviation (SD). Data were subjected to the $t$ - test. All calculations were performed with Microsoft Excel (Version 4, statistical functions, Microsoft Corp., Redmond, WA, USA). 


\section{Results and discussion}

\section{1. pH}

During storage period, $\mathrm{pH}$ value of treated as well as untreated fruits did not change statistically significantly and was between 3.60-3.76 for Victoria (Table 1) and between 3.75-3.99 for Camarosa (Table 2). This fact indicates that there was no hydrolyses of proteins and no change in organic acids concentration during storage period, i.e. conditions for cold storage was chosen properly.

Proximate chemical composition of Victoria

\begin{tabular}{|c|c|c|c|c|c|c|}
\hline \multicolumn{2}{|c|}{$\begin{array}{c}\text { Storage } \\
\text { period }\end{array}$} & pH & $\begin{array}{l}\text { Vitamin C } \\
\text { mg100g }^{-1}\end{array}$ & $\begin{array}{c}\text { Total } \\
\text { Anthocyanins } \\
\operatorname{mg100g}^{-1}\end{array}$ & $\begin{array}{c}\text { TPC } \\
\text { mg100g }^{-1}\end{array}$ & $\begin{array}{l}\text { FRAP mg } \\
\text { equivalents } \\
\text { of vitamin C } \\
\times 100 \mathrm{~g}^{-1}\end{array}$ \\
\hline \multirow{2}{*}{\multicolumn{2}{|c|}{ Initial }} & 3.60 & 45.60 & 21.35 & 129.86 & 206.46 \\
\hline & & $\pm 0.18^{\mathrm{a}}$ & $\pm 2.28^{\mathrm{a}}$ & $\pm 1.06^{\mathrm{a}}$ & $\pm 6.49^{\mathrm{a}}$ & $\pm 10.32^{\mathrm{a}}$ \\
\hline \multirow{4}{*}{$\begin{array}{l}\text { After } 4 \\
\text { days }\end{array}$} & $\mathrm{C}$ & 3.69 & 56.40 & 17.09 & 134.23 & 185.70 \\
\hline & & $\pm 0.18^{\mathrm{a}}$ & $\pm 2.82^{\mathrm{b}}$ & $\pm 0.85^{\mathrm{b}}$ & $\pm 6.71^{\mathrm{a}}$ & $\pm 9.28^{\mathrm{b}}$ \\
\hline & TS & 3.79 & 61.20 & 20.21 & 140.85 & 202.12 \\
\hline & & $\pm 0.19^{\mathrm{a}}$ & $\pm 3.06^{\mathrm{b}}$ & $\pm 1.01^{\mathrm{a}}$ & $\pm 7.04^{\mathrm{a}}$ & $\pm 10.10^{\mathrm{a}}$ \\
\hline \multirow{4}{*}{$\begin{array}{l}\text { After } 7 \\
\text { days }\end{array}$} & $\mathrm{C}$ & 3.68 & 52.80 & 15.79 & 130.92 & 136.08 \\
\hline & & $\pm 0.18^{\mathrm{a}}$ & $\pm 2.64^{\mathrm{b}}$ & $\pm 0.78^{\mathrm{b}}$ & $\pm 5.23^{\mathrm{a}}$ & $\pm 6.80^{\mathrm{c}}$ \\
\hline & TS & 3.80 & 55.20 & 19.50 & 137.56 & 177.25 \\
\hline & & $\pm 0.19^{\mathrm{a}}$ & $\pm 2.76^{\mathrm{b}}$ & $\pm 0.97^{\mathrm{c}}$ & $\pm 6.87^{\mathrm{a}}$ & $\pm 8.86^{\mathrm{b}}$ \\
\hline \multirow{4}{*}{$\begin{array}{l}\text { After } \\
10 \text { days }\end{array}$} & $\mathrm{C}$ & 3.77 & 41.00 & 13.95 & 126.57 & 130.38 \\
\hline & & $\pm 0.17^{\mathrm{a}}$ & $\pm 2.05^{\mathrm{c}}$ & $\pm 0.69^{\mathrm{d}}$ & $\pm 6.32^{\mathrm{a}}$ & $\pm 6.51^{\mathrm{c}}$ \\
\hline & TS & 3.82 & $49.25 \pm$ & 18.91 & 141.95 & 169.14 \\
\hline & & $\pm 0.20^{\mathrm{a}}$ & $\pm 2.46^{\mathrm{d}}$ & $\pm 0.94^{\mathrm{c}}$ & $\pm 7.10^{\mathrm{a}}$ & $\pm 8.45^{\mathrm{b}}$ \\
\hline \multirow{4}{*}{$\begin{array}{l}\text { After } \\
13 \text { days }\end{array}$} & $\mathrm{C}$ & 3.76 & 22.55 & 13.35 & 111.15 & 120.02 \\
\hline & & $\pm 0.17^{\mathrm{a}}$ & $\pm 1.12^{\mathrm{e}}$ & $\pm 0.66^{\mathrm{d}}$ & $\pm 5.55^{\mathrm{b}}$ & $\pm 6.00^{\mathrm{d}}$ \\
\hline & $\mathrm{TS}$ & 3.95 & 38.95 & 15.49 & 138.00 & 157.61 \\
\hline & & $\pm 0.20^{\mathrm{b}}$ & $\pm 1.94^{\mathrm{f}}$ & $\pm 0.77^{\mathrm{b}}$ & $\pm 6.90^{\mathrm{a}}$ & $\pm 7.88^{\mathrm{e}}$ \\
\hline
\end{tabular}

${ }^{*} \mathrm{C}$-control; **TS-treated samples

*-Values within a column with different letters are significantly different by ANOVA with Tukey's HSD tests at $\mathrm{p}<0.05$.

\subsection{Content of vitamin $\mathrm{C}$}

Vitamin C content in the fruits of Victoria increased after treatment from $45.60 \pm 2.28$ to

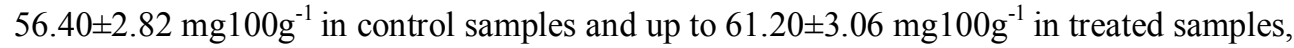
and stayed on this level until 7-th day. Increasing of vitamin $\mathrm{C}$ content was caused, probably, because of the prolonged ripening process in fruits during first storage days [25]. After 7-th day content of vitamin $\mathrm{C}$ declined due to destruction of vitamins caused by oxidation process [32-36]. On the 13-th day, it was $22.55 \pm 1.12$ and $38.95 \pm 1.94 \mathrm{mg} 100 \mathrm{~g}^{-1}$ in control and treated samples respectively. Thus, treatment with MJ, SA and AA positively influenced on the level of content of vitamin $\mathrm{C}$ in Victoria strawberries fruits during storage. 
As to the fruits of Camarosa, because of oxidation process again, vitamin $\mathrm{C}$ content decreased monotonically in the control and treated samples as well, and at the end of experiment it was about half of the initial level. There was no statistically significant difference between content of vitamin $\mathrm{C}$ in the control and treated samples (Table 2). So, in case of Camarosa fruits, no effect of treatment with MJ, SA and AA on the content of vitamin $\mathrm{C}$ was found.

Proximate chemical composition of Camarosa

Table 2

\begin{tabular}{|c|c|c|c|c|c|c|}
\hline \multicolumn{2}{|c|}{$\begin{array}{c}\text { Storage } \\
\text { period }\end{array}$} & pH & $\begin{array}{c}\text { Vitamin } \\
\mathrm{C} \\
\text { mg100g }^{-1}\end{array}$ & $\begin{array}{c}\text { Total } \\
\underset{\text { Anthocyanins }}{\text { mg100g }^{-1}}\end{array}$ & $\begin{array}{c}\text { TPC } \\
\text { mg100g }^{-1}\end{array}$ & $\begin{array}{c}\text { FRAP mg } \\
\text { equivalents } \\
\text { vitamin C } \\
\times 100 \mathrm{~g}^{-1}\end{array}$ \\
\hline \multicolumn{2}{|l|}{ Initial } & $\begin{array}{c}3.75 \\
\pm 0.15^{\mathrm{a}}\end{array}$ & $\begin{array}{c}56.40 \\
\pm 2.82^{\text {a }}\end{array}$ & $\begin{array}{l}46.93 \\
\pm 2.34^{\mathrm{a}}\end{array}$ & $\begin{array}{l}181.51 \\
\pm 9.07^{\mathrm{a}}\end{array}$ & $\begin{array}{c}370.23 \\
\pm 18.51^{\mathrm{a}}\end{array}$ \\
\hline \multirow[t]{2}{*}{$\begin{array}{l}\text { After } 4 \\
\text { days }\end{array}$} & $\mathrm{C}$ & $\begin{array}{c}3.78 \\
\pm 0.15^{\mathrm{a}}\end{array}$ & $\begin{array}{c}58.80 \\
\pm 2.94^{\mathrm{a}}\end{array}$ & $\begin{array}{c}35.03 \\
\pm 1.75^{\mathrm{b}}\end{array}$ & $\begin{array}{l}188.10 \\
\pm 9.40^{\mathrm{a}}\end{array}$ & $\begin{array}{c}352.30 \\
\pm 17.61^{\mathrm{a}}\end{array}$ \\
\hline & $\mathrm{TS}$ & $\begin{array}{c}3.82 \\
\pm 0.19^{\mathrm{a}}\end{array}$ & $\begin{array}{c}62.40 \\
\pm 3.12^{\mathrm{a}}\end{array}$ & $\begin{array}{l}48.43 \\
\pm 2.42^{\mathrm{a}}\end{array}$ & $\begin{array}{l}197.80 \\
\pm 9.89^{\mathrm{a}}\end{array}$ & $\begin{array}{c}368.45 \\
\pm 18.42^{\mathrm{a}}\end{array}$ \\
\hline \multirow[t]{2}{*}{$\begin{array}{l}\text { After } 7 \\
\text { days }\end{array}$} & $\mathrm{C}$ & $\begin{array}{c}3.87 \\
\pm 0.18^{\mathrm{a}}\end{array}$ & $\begin{array}{l}43.20 \\
\pm 2.16^{\mathrm{b}}\end{array}$ & $\begin{array}{l}30.15 \\
\pm 1.50^{\mathrm{c}}\end{array}$ & $\begin{array}{l}162.83 \\
\pm 8.14^{\mathrm{b}}\end{array}$ & $\begin{array}{c}281.60 \\
\pm 14.08^{\mathrm{b}}\end{array}$ \\
\hline & TS & $\begin{array}{c}3.80 \\
\pm 0.18^{\mathrm{a}}\end{array}$ & $\begin{array}{l}45.60 \\
\pm 2.28^{b}\end{array}$ & $\begin{array}{l}42.20 \\
\pm 2.11^{\mathrm{a}}\end{array}$ & $\begin{array}{l}184.81 \\
\pm 9.24^{\mathrm{a}}\end{array}$ & $\begin{array}{c}319.99 \\
\pm 15.99^{\mathrm{c}}\end{array}$ \\
\hline \multirow[t]{2}{*}{$\begin{array}{l}\text { After } 10 \\
\text { days }\end{array}$} & $\mathrm{C}$ & $\begin{array}{c}3.90 \\
\pm 0.19^{\mathrm{a}}\end{array}$ & $\begin{array}{r}28.70 \\
\pm 1.43^{\mathrm{c}}\end{array}$ & $\begin{array}{c}26.28 \\
\pm 1.31^{\mathrm{d}}\end{array}$ & $\begin{array}{l}160.32 \\
\pm 8.01^{\mathrm{b}}\end{array}$ & $\begin{array}{c}216.30 \\
\pm 10.81^{d}\end{array}$ \\
\hline & TS & $\begin{array}{c}3.84 \\
\pm 0.19^{\mathrm{a}}\end{array}$ & $\begin{array}{c}30.75 \\
\pm 1.53^{\mathrm{c}}\end{array}$ & $\begin{array}{c}38.17 \\
\pm 1.90^{\mathrm{b}}\end{array}$ & $\begin{array}{l}180.11 \\
\pm 9.00^{\mathrm{a}}\end{array}$ & $\begin{array}{c}277.98 \\
\pm 13.89^{\mathrm{b}}\end{array}$ \\
\hline \multirow[t]{2}{*}{$\begin{array}{l}\text { After } 13 \\
\text { days }\end{array}$} & $\mathrm{C}$ & $\begin{array}{c}3.99 \\
\pm 0.20^{\mathrm{a}}\end{array}$ & $\begin{array}{l}23.40 \\
\pm 1.17^{\mathrm{d}}\end{array}$ & $\begin{array}{l}20.41 \\
\pm 1.02^{\text {e }}\end{array}$ & $\begin{array}{l}131.00 \\
\pm 6.55^{\mathrm{c}}\end{array}$ & $\begin{array}{c}201.14 \\
\pm 10.05^{\mathrm{d}}\end{array}$ \\
\hline & TS & $\begin{array}{c}3.83 \\
\pm 0.18^{\mathrm{a}}\end{array}$ & $\begin{array}{c}25.42 \\
\pm 2.27^{\text {d }}\end{array}$ & $\begin{array}{c}34.59 \\
\pm 1.72^{\mathrm{b}}\end{array}$ & $\begin{array}{l}150.02 \\
\pm 7.50^{\mathrm{d}}\end{array}$ & $\begin{array}{c}248.25 \\
\pm 12.41^{\mathrm{e}}\end{array}$ \\
\hline
\end{tabular}

*C-control; **TS-treated samples

*-Values within a column with different letters are significantly different by ANOVA with Tukey's HSD tests at $\mathrm{p}<0.05$.

\subsection{Content of total anthocyanins}

Total anthocyanins in the control samples of Victoria gradually decreased from $21.35 \pm 1.06$ to $13.35 \pm 0.66 \mathrm{mg} 100 \mathrm{~g}^{-1}$ on the 13 -th day of storage. The reason for reduction of anthocyanins quantity may be their oxidation process [37]. As to the treated samples, anthocyanins content reduced to $15.49 \pm 0.77 \mathrm{mg} 100 \mathrm{~g}^{-1}$. Difference between control and treated samples at the end of experiment was statistically significant but practically insignificant (Table 1).

In the samples of Camarosa total anthocyanins reduced from $46.93 \pm 2.34$ to $20.41 \pm 1.02$ and to $34.59 \pm 1.72 \mathrm{mg}$ per $100 \mathrm{~g}$ fruits in control and treated samples respectively. Difference between control and treated samples at the end of experiment was statistically and practically significant as well (Table 2). Thus, in case of Camarosa, application of combined solution of methyl jasmonate, salicylic acid and ascorbic acid positively influenced on storability of strawberry fruits. 


\subsection{TPC}

Total phenolic compounds in the control samples of Victoria initially was equal to $129.86 \pm 6.49 \mathrm{mg} 100 \mathrm{~g}^{-1}$ and at the end of experiment it reduced to $111.15 \pm 5.55$, that is by $17 \%$. Degradation of phenolic compounds was. Probably, caused by their oxidation [38.39]. Whereas, in the treated sample TPC was unchanged (Table 1), assumingly due to the treatment effect.

TPC in Camarosa initially was by $40 \%$ more than in Victoria, i.e. $181.51 \pm 9.07$ $\mathrm{mg} 100 \mathrm{~g}^{-1}$. After 13 days of storage, TPC reduced to $131.00 \pm 6.55$ and to $150.02 \pm 7.50$ $\mathrm{mg} 100 \mathrm{~g}^{-1}$ in the control and treated samples respectively (Table 2). Effect of treatment was statistically and practically significant. From these data, we can conclude, that combined solution of MJ, SA and AA effectively inhibited oxidation process of phenolic compounds in the fruits of strawberry of Victoria and Camarosa varieties.

\subsection{FRAP assay}

It is well known that antioxidant activity of fruits is proportional to the phenolic compounds content [40.41]. Therefore, it was not surprising that antioxidant activity monotonically decreased in the control samples of Victoria from $206.46 \pm 10.32$ at the first day to $120.02 \pm 6.00 \mathrm{mg}$ equivalents of vitamin-C per $100 \mathrm{~g}$ fruits at the end of the experiment. Change in antioxidant activity of the treated samples of Victoria was less significant: from $206.46 \pm 10.32$ to $157.61 \pm 7.88$ units, that is by $17.9 \%$ less than in the case of control samples.

Antioxidant activity of fruits of Camarosa initially was by $80 \%$ more than that of Victoria fruits. During storage period, antioxidant activity of the fruits of Camarosa decreased gradually. After 13 days of storage, it was equal to $201.14 \pm 10.05$ and $248.25 \pm 12.41$ units for untreated and treated samples respectively (Table 2). Thus, the effect of treatment was statistically and practically significant, i.e. $23.3 \%$.

\subsection{Individual anthocyanins}

Main anthocyanin in the fruits of both varieties was Pelargonidin-3-O-glucoside. This is a common case for strawberry fruits [42]. Its initial content in the fruits was $68.45 \pm 3.42$ and $65.28 \pm 3.26 \%$ of total anthocyanins for Victoria and Camarosa varieties respectively. Though total anthocyanins content gradually decreased during storage period, percentage of this anthocyanin did not change during storage days (Table 3). This indicates on the fact, that Pelargonidin-3-O-glucoside remained the main anthocyanin during whole period of storage. In Victoria variety Pelargonidin-3-acetyl-glucoside was the second anthocyanin by quantity - its percentage in the treated and untreated samples was about $10 \%$ and did not changed during storage. Percentage of this anthocyanin in the Camarosa variety varied nonmonotonically during storage time. Non-monotonical changes of percentage of individual anthocyanins, assumingly, was a result of the fact that quantity of various anthocyanins were changing differently during storage period. In Camarosa Cyanidin-3-O-glucoside was the second anthocyanin by quantity, its percentage changed during storage period from $10.25 \pm 0.51$ to $9.41 \pm 0.47$ and $8.10 \pm 0.40 \%$ for untreated and treated fruit samples respectively. Pelargonidin-3-O- rutinoside was one more anthocyanins detected in both varieties of strawberry. Its initial percentage was equal to $6.14 \pm 0.30$ and $8.23 \pm 0.41 \%$ in Victoria and Camarosa varieties respectively. Cyanidin-3-O-rutinoside was presented in the smallest quantity in both varieties. Its percentage was less than $1 \%$ and did not change practically during storage time. 
Table 3

Individual Anthocyanins in Strawberry cultivars (\%)

\begin{tabular}{|c|c|c|c|c|c|c|c|}
\hline Cultivars & \multicolumn{2}{|c|}{ Storage period } & 1 & 2 & 3 & 4 & 5 \\
\hline \multirow{10}{*}{ Victoria } & \multicolumn{2}{|c|}{ Initial } & 5.44 & 0.17 & 68.45 & 6.14 & 10.03 \\
\hline & \multirow{3}{*}{ After 4 days } & 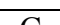 & 520 & 021 & 6004 & 765 & 083 \\
\hline & & $C$ & $\begin{array}{c}5.39 \\
\pm 0.26^{\mathrm{a}}\end{array}$ & $\begin{array}{c}0.21 \\
\pm 0.01^{b}\end{array}$ & $\begin{array}{r}69.04 \\
\pm 3.45^{\mathrm{a}}\end{array}$ & $\begin{array}{c}1.65 \\
\pm 0.38^{\mathrm{b}}\end{array}$ & $\begin{array}{c}9.83 \\
\pm 0.49^{\mathrm{a}}\end{array}$ \\
\hline & & TS & $\begin{array}{c}6.30 \\
\pm 0.31^{\mathrm{b}}\end{array}$ & $\begin{array}{c}0.19 \\
\pm 0.009^{\mathrm{c}}\end{array}$ & $\begin{array}{c}69.19 \\
\pm 3.46^{\text {a }}\end{array}$ & $\begin{array}{c}6.45 \\
\pm 0.32^{\mathrm{a}}\end{array}$ & $\begin{array}{c}9.13 \\
\pm 0.45^{\mathrm{a}}\end{array}$ \\
\hline & \multirow{2}{*}{ After 7 days } & $\mathrm{C}$ & $\begin{array}{c}7.71 \\
\pm 0.38^{\mathrm{c}}\end{array}$ & $\begin{array}{c}0.23 \\
\pm 0.01^{\mathrm{d}}\end{array}$ & $\begin{array}{c}65.95 \\
\pm 3.29^{\mathrm{a}}\end{array}$ & $\begin{array}{c}7.44 \\
\pm 0.37^{\mathrm{b}}\end{array}$ & $\begin{array}{c}10.33 \\
\pm 0.51^{\text {a }}\end{array}$ \\
\hline & & $\mathrm{TS}$ & $\begin{array}{c}6.76 \\
\pm 0.33^{\mathrm{b}}\end{array}$ & $\begin{array}{c}0.22 \\
\pm 0.01^{\text {bd }}\end{array}$ & $\begin{array}{c}66.87 \\
\pm 3.34^{\mathrm{a}}\end{array}$ & $\begin{array}{c}6.59 \\
\pm 0.32^{\mathrm{a}}\end{array}$ & $\begin{array}{c}10.06 \\
\pm 0.50^{\mathrm{a}}\end{array}$ \\
\hline & \multirow{2}{*}{ After 10 days } & $\mathrm{C}$ & $\begin{array}{c}5.23 \\
\pm 0.26^{\mathrm{a}}\end{array}$ & $\begin{array}{c}0.20 \\
\pm 0.02^{\text {bd }}\end{array}$ & $\begin{array}{c}69.45 \\
\pm 3.47^{\mathrm{a}}\end{array}$ & $\begin{array}{c}6.12 \\
\pm 0.30^{\mathrm{a}}\end{array}$ & $\begin{array}{c}8.09 \\
\pm 0.40^{\mathrm{b}}\end{array}$ \\
\hline & & TS & $\begin{array}{c}6.19 \\
\pm 0.38^{\mathrm{a}}\end{array}$ & $\begin{array}{c}0.24 \\
\pm 0.01^{\mathrm{d}}\end{array}$ & $\begin{array}{c}68.01 \\
\pm 3.40^{\mathrm{a}}\end{array}$ & $\begin{array}{c}7.33 \\
\pm 0.36^{\mathrm{b}}\end{array}$ & $\begin{array}{c}9.38 \\
\pm 0.47^{\mathrm{a}}\end{array}$ \\
\hline & \multirow{2}{*}{ After 13 days } & $\mathrm{C}$ & $\begin{array}{c}8.27 \\
\pm 0.41^{\mathrm{c}}\end{array}$ & $\begin{array}{c}0.23 \\
\pm 0.01^{\text {bd }}\end{array}$ & $\begin{array}{c}66.29 \\
\pm 3.31^{\text {a }}\end{array}$ & $\begin{array}{c}6.02 \\
\pm 0.30^{\mathrm{b}}\end{array}$ & $\begin{array}{c}8.22 \\
\pm 0.41^{\mathrm{b}}\end{array}$ \\
\hline & & TS & $\begin{array}{c}8.69 \\
\pm 0.43^{\mathrm{c}}\end{array}$ & $\begin{array}{c}0.35 \\
\pm 0.02^{\mathrm{e}}\end{array}$ & $\begin{array}{c}64.84 \\
\pm 3.24^{\mathrm{a}}\end{array}$ & $\begin{array}{c}5.47 \\
\pm 0.27^{\mathrm{c}}\end{array}$ & $\begin{array}{c}9.10 \\
\pm 0.45^{\mathrm{a}}\end{array}$ \\
\hline \multirow{9}{*}{ Camarosa } & \multicolumn{2}{|l|}{ Initial } & $\begin{array}{c}9.28 \\
\pm 0.46^{\mathrm{a}}\end{array}$ & $\begin{array}{c}0.48 \\
\pm 0.02^{\mathrm{a}}\end{array}$ & $\begin{array}{c}65.28 \\
\pm 3.26^{\mathrm{a}}\end{array}$ & $\begin{array}{c}8.23 \\
\pm 0.41^{\mathrm{a}}\end{array}$ & $\begin{array}{c}7.01 \\
\pm 0.35^{\mathrm{a}}\end{array}$ \\
\hline & \multirow{2}{*}{ After 4 days } & $\mathrm{C}$ & $\begin{array}{c}10.25 \\
\pm 0.51^{\text {a }}\end{array}$ & $\begin{array}{c}0.63 \\
\pm 0.03^{\mathrm{b}}\end{array}$ & $\begin{array}{c}65.40 \\
\pm 3.27^{\mathrm{a}}\end{array}$ & $\begin{array}{c}11.71 \\
\pm 0.58^{\mathrm{b}}\end{array}$ & $\begin{array}{c}3.13 \\
\pm 0.15^{\mathrm{b}}\end{array}$ \\
\hline & & TS & $\begin{array}{c}7.81 \\
\pm 0.39^{b}\end{array}$ & $\begin{array}{c}0.46 \\
\pm 0.02^{\mathrm{a}}\end{array}$ & $\begin{array}{c}68.68 \\
\pm 3.43^{\text {a }}\end{array}$ & $\begin{array}{c}8.72 \\
\pm 0.43^{\mathrm{a}}\end{array}$ & $\begin{array}{c}4.12 \\
\pm 0.20^{\mathrm{c}}\end{array}$ \\
\hline & \multirow{2}{*}{ After 7 days } & $\mathrm{C}$ & $\begin{array}{c}9.29 \\
\pm 0.46^{\mathrm{a}}\end{array}$ & $\begin{array}{c}0.70 \\
\pm 0.03^{\mathrm{c}}\end{array}$ & $\begin{array}{c}65.50 \\
\pm 3.27^{\mathrm{a}}\end{array}$ & $\begin{array}{l}13.93 \\
\pm 0.69^{\mathrm{c}}\end{array}$ & $\begin{array}{c}1.57 \\
\pm 0.07^{\mathrm{d}}\end{array}$ \\
\hline & & TS & $\begin{array}{c}10.58 \\
\pm 0.52^{\mathrm{a}}\end{array}$ & $\begin{array}{c}0.59 \\
\pm 0.03^{\mathrm{b}}\end{array}$ & $\begin{array}{c}64.00 \\
\pm 3.20^{\mathrm{a}}\end{array}$ & $\begin{array}{c}10.67 \\
\pm 0.53^{\mathrm{b}}\end{array}$ & $\begin{array}{c}4.62 \\
\pm 0.23^{\mathrm{e}}\end{array}$ \\
\hline & \multirow{2}{*}{ After 10 days } & $\mathrm{C}$ & $\begin{array}{c}11.41 \\
\pm 0.57^{\mathrm{a}}\end{array}$ & $\begin{array}{c}0.65 \\
\pm 0.03^{\mathrm{b}}\end{array}$ & $\begin{array}{c}65.81 \\
\pm 3.29^{\mathrm{a}}\end{array}$ & $\begin{array}{c}10.08 \\
\pm 0.50^{\mathrm{b}}\end{array}$ & $\begin{array}{c}2.23 \\
\pm 0.11^{\mathrm{f}}\end{array}$ \\
\hline & & TS & $\begin{array}{c}9.12 \\
\pm 0.45^{\mathrm{a}}\end{array}$ & $\begin{array}{c}0.31 \\
\pm 0.01^{\mathrm{d}}\end{array}$ & $\begin{array}{c}62.73 \\
\pm 3.13^{\mathrm{a}}\end{array}$ & $\begin{array}{c}4.11 \\
\pm 0.20^{\mathrm{d}}\end{array}$ & $\begin{array}{c}12.26 \\
\pm 0.61^{\mathrm{g}}\end{array}$ \\
\hline & \multirow{2}{*}{ After 13 days } & $\mathrm{C}$ & $\begin{array}{c}9.41 \\
\pm 0.47^{\mathrm{a}}\end{array}$ & $\begin{array}{c}0.62 \\
\pm 0.03^{\mathrm{b}}\end{array}$ & $\begin{array}{c}67.81 \\
\pm 3.39^{\mathrm{a}}\end{array}$ & $\begin{array}{c}10.16 \\
\pm 0.50^{b}\end{array}$ & $\begin{array}{c}2.02 \\
\pm 0.10^{\mathrm{f}}\end{array}$ \\
\hline & & TS & $\begin{array}{c}8.10 \\
\pm 0.40^{b}\end{array}$ & $\begin{array}{c}0.32 \\
\pm 0.01^{\mathrm{d}}\end{array}$ & $\begin{array}{c}63.73 \\
\pm 3.18^{\mathrm{a}}\end{array}$ & $\begin{array}{c}4.00 \\
\pm 0.20^{\mathrm{d}}\end{array}$ & $\begin{array}{c}11.30 \\
\pm 0.56^{\mathrm{g}}\end{array}$ \\
\hline
\end{tabular}

*C-control; **TS-Treated samples

1.Cyanidin-3-O-glucoside

2.Cyanidin-3-O-rutinoside

3.Pelargonidin-3-O-glucoside

4.Pelargonidin-3-O- rutinoside

5.Pelargonidin-3-acetyl-glucoside

* Values within a column with different letters are significantly different by ANOVA with Tukey's HSD tests at $\mathrm{p}<0.05$ 


\subsection{Texture analysis}

The curve showing load resulting from deformation of fruit was linear for all samples (Fig.1).At the start of experiment for control samples of Victoria fruits, work required for rupture of fruits was equal to $20.6 \pm 4.7 \mathrm{Nmm}$, and at the end of the experiment, it was equal to10.8 $\pm 4.8 \mathrm{Nmm}$. For the treated samples of Victoria this parameter changed from 25.1 \pm 9.8 to $17.8 \pm 4.5 \mathrm{Nmm}$. Camarosa fruits were more resistant against load force. Work to rupture untreated samples of Camarosa was equal $46.5 \pm 13.2 \mathrm{Nmm}$ at the start of experiment and reduced to $30.4 \pm 5.5 \mathrm{Nmm}$ after 13 days of storage. As to the treated samples of Camarosa, this parameter was $43.2 \pm 6.3 \mathrm{Nmm}$ on the first day of experiment, and $32.6 \pm 5.5 \mathrm{Nmm}$ on the 13-th day of storage. Thus, treatment with combined solution resulted in improvement of texture of fruits during storage process.

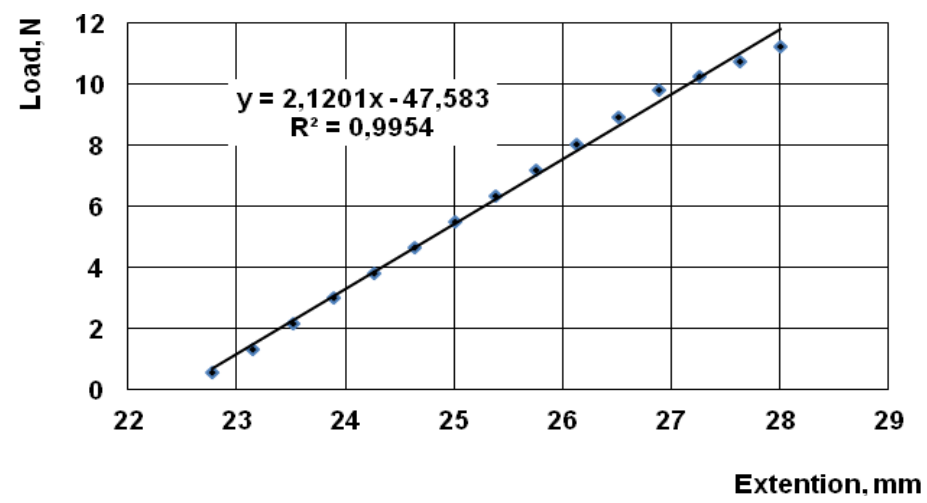

Figure 1. Load dependance on extention in camarosa fruits, control samples, first day

\section{Conclusions}

Treatment of fruits of strawberry with combined solutions of methyl jasmonate, salicylic acid and ascorbic acid positively influenced on storability of the fruits. Maintenance of anthocyanins and total phenolics as well as antioxidant potential during storage period was statistically significantly increased. Treatment with combined solution resulted in improvement of texture of fruits during storage process.

Acknowledgements. The authors declare no conflicts of interest. The research was carried out in the framework of the research task financed by Shota Rustaveli National Science Foundation (SRNSF), 216736.

\section{References}

1. Talcott S.T. (2007), Chapter 2. Chemical components of berry fruits. In: Yanyun Zhao (ed). Berry fruit, value-Added products for health promotion, CRC Press, pp. 51-73. 
2. Hakala M., Lapvetelainen A., Huopalahti R., Kallio H., Tahvonen R. (2003), Effects of varieties and cultivation conditions on the composition of strawberries, Journal of Food Composition and Analysis, 16, pp. 67-80.

3. Skrovankova S., Sumczynski D., Mlcek J., Jurikova T., Sochor J. (2015), Bioactive compounds and antioxidant activity in different types of berries. International Journal of Molecular Sciences, Basel, 16, pp. 24673-24706.

4. Slatnar A., Jakopic J., Stampar F., Vebric R., Jamnik P. (2012), The effect of bioactive compounds on in vitro and in vivo antioxidant activity of different berry juices, PLoS ONE, San Francisco, 7(10), pp. e47880-1-e47880-8.

5. Namiesnik J., Vearasilp K., Nemirovski A., Leontowicz H., leontowicz M., Pasko P., martinez0zyala A.L., Gonzalez-agular G.A., Suhaj M., Gorinstein S. (2014), In vitro studies on the relationship between the antioxidant activities of some berry extracts and their binding properties to serum albumin, Applied of Biochemistry and Biotechnology, 182, pp. 2849-2865.

6. Diaconeasa Z., Ranga F., Rugina F., Leopold L., Pop O., Vodnar D., Cuibus L., Socaciu C. (2015), Phenolic content and their antioxidant activity in various berries cultivated in Romania. Journal of Food Science and Technology, Oxford, 72(1), pp. 99-103.

7. Rice-Evans C.A., MillerN.J. (1996), Antioxidant activities of flavonoids as bioactive components of food. Biochemical Society Transactions, 24, pp. 790-795.

8. Heinonen I.M., MeyerA.S., FrankelE.N. (1998), Antioxidant activity of berry phenolics on human low-density lipoprotein and liposome oxidation, Jounal of Agricultural and Food Chemistry, 46, pp. 4107-4112.

9. Wills R.B.H. (1998), Enhancement of senescence in non-climacteric fruit and vegetables by low ethylene levels, Acta Horticulturae, 464, pp. 159-162.

10. De Antos B., Sanchez -Moreno C., De Pascual-Teresa S., Cano M.P. (2006), Freezing Principles, In: Y.H.Hui (ed.), Handbook of Fruit and Fruit Processig, Blackwell Publishing, pp. 59-80.

11. Raskin I. (1992), Role of salicylic acid in plants, Annual review of plant physiology and plant molecular biology, 43, pp. 439-463.

12. Turner J.G., Ellis C., Devoto A. (2002), The jasmonate signal pathway, Plant Cell, 14, pp. 153164.

13. Ueda, J. Saniewski, J. (2006), Methyl jasmonate-induced stimulation of chlorophyll formation in the basal part of tulip bulbs kept under natural light conditions, Journal of fruit and ornamental plant research, 14, pp. 199-210.

14. AliM.B., Hahn, E., Paek, K. (2007), Methyl jasmonate and salicylic acid induced oxidative stress and accumulation of phenolics in panax ginseng bioreactor root suspension cultures. Molecules, 12, pp. 607-621.

15. Cardemil TL., Nunes-Nesi A.,Retamales J., Jaakola L., Alberdi M., Ribera-Fonseca A. (2016), Methyl Jasmonate: An Alternative for Improving the Quality and Health Properties of Fresh Fruits, Molecules, 21, pp. 567, DOI:10.3390/moleculeas21060567

16. Zavala J.F.A., Wang S.Y., Wang C.Y., Aguilar G.A.G.(2004), Effects of Storage Temperatures on Antioxidant Capacity and Aroma Compounds in Strawberry Fruit, Elsevier Ltd. on behalf of Swiss Society of Food Science \& Technology.

17. Wang L., Li S. (2008), Role of Salicylic acid in postharvest Physiology, Fresh produce 2(1), pp.1-5.

18. Sapers G.M. (1993), Browning of foods: control by sulfites, antioxidants and other means, Food Technology, 47, pp.75-84.

19. Chiabrando V., Giacalone G. (2012), Effect of antibrowning agents on color and related enzymes in fresh-cut apples during cold storage, Journal of Food Processing and Preservation, 36, pp. 133-140.

20. Gomez P.L., Garcia-Loredo A., Nieto A., Salvadori A., Guerrero S., Alzamora S.M. (2012), Effect of pulsed light combined with an antibrowning pretreatment on quality fresh-cut apple, Innovative Food Science and Emerging Technology, 46, pp.102-112.

21. Remorini D., Landi M., Tardelli F., Lugani A., Massai R., Graziani G., Fogliano V., Guidi L. (2015), Effect of chlorine dioxide and ascorbic acid on enzymatic browning and fresh-cut red 
delicious and granny smith apples, Journal of Food Processing and Preservation, 39, pp. 29252934.

22. Alscher R.G., Donahue J.L., Cramer C.L. (1997), Reactive oxygen species and antioxidants: Relationship in green cells, Physiologia Plantarum, 100, pp. 224-233.

23. Osuga D., Van der Schaaf A. Whitaker J.R. (1994), Control of polyphenol oxidase activity using a catalytic mechanism. In: (R.Y. Yada, R.L. Jackman and J.L. Smith, (eds.) Protein StructureFunction Relationships in Foods, pp. NY, Springer, pp. 62-88.

24. Landi M., Deglinnocenti E., guglielminetti L., Guidi L. (2013), Role of ascorbic acid in polyphenol-oxidase inhibition and browning prevention in different browning-sensitive Lactuca sativa var. capitata (L.) and Eruca sativa (Mill.) stored as fresh-cut products, Journal of the science of food and agriculture, 93, pp. 1814-1819.

25. Koyunce M.A., Dilmagunal T. (2012), Determination of vitamin C and organic acid changes in strawberry by HPLC during cold storage, Notulae Botanicae Horti Agrobotanici, 38 (3), pp. 9598.

26. Rodrigues-Saona L.E., Wrolstad R.E. (2001), Extraction, isolation and purification of Anthocyanins. In: Wrolstad, R. E. (Ed.). Current protocols in food analytical chemistry. Hoboken: John Wiley \& Sons.

27. Prior R.L., Cao G., Martin A., Sofic E., Mcewen J., O’brien C., Lischner N., Ehlenfeldt M., Kalt W., Krewer G., Mainland C.M. (1998), Antioxidant capacity as influenced by total phenolic and anthocyanin content, maturity, and variety of vaccinium species, Journal of Agricultural and Food Chemistry, 46, pp. 2686-2693.

28. Tosun I., Ustun N.S., Tekguler B. (2008), Physical and chemical changes during ripening of blackberry fruits, Scientia Agricola, 65, pp. 87-90.

29. Giusti M.M., Wrolstad R.E. (2001), Characterization and measurement with UV visible spectroscopy. In: Wrolstad R. E. (Ed.), Current protocols in food analytical chemistry, John Wiley \& Sons.

30. Bond T.J., Lewis J.R., Davis A., Davis A.P. (2003), Analysis and Purification of Catechins and Their Transformation Products. In C. Santos-Bulga, G. Williamson (Eds.), Methods of polyphenols analysis, UK, The Royal Society of Chemistry, pp. $229-265$.

31. Benzie I.F.F., Strain J.J. (1996), The ferric reducing ability of plasma (FRAP) as a measure of "antioxidant power": the FRAP assay. Analytical Biochemistry, 239, pp.70 - 76.

32. Howard L.A., Wong A.D., Perry A.K., Klein B.P. (1999), Beta-carotene and ascorbic acid retention in fresh and processed vegetables, Journal of Food science, 64, pp. 929-936, DOI: 10.1111/j.1365-2621.1999.tb15943.

33. Lisiewska Z., Słupski J., Zuchowicz E. (2003), Effect of temperature and storage period on the preservation of vitamin $\mathrm{C}$, thiamine and riboflavin in frozen dill (Anethum graveolens L.), Electronic Journal of Polish Agricultural Universities, 6, pp. 1-7.

34. Phillips K.M., Tarragó-Trani M.T., Gebhardt S.E., Exler J., Patterson K.Y., Haytowitz D.B., Pehrsson P.R., Holden J.M. (2010), Stability of vitamin C in frozen raw fruit and vegetable homogenates, Journal of Food Composition and Analysis, 23, pp. 253-259, DOI:10.1016/j.jfca.2009.08.018.

35. Cätunescu G.M., Tofanä, M., Mureșan C., Ranga F., David A., Muntean M. (2012), The Effect of Cold Storage on Some Quality Characteristics of Minimally Processed Parsley (Petroselinum crispum), Dill (Anethum graveolens) and Lovage (Levisticum officinale), The Bulletin of University of Agricultural Sciences and Veterinary Medicin Cluj-Napoca, 6, pp. 213-221.

36. Cho K.S., Jeong H.J., Cho J.H., Park Y.E., Hong S.Y., Won H.S., Kim H.J. (2013), Vitamin C content of potato clones from Korean breeding lines and compositional changes during growth and after storage. Horticulture, Environment and Biotechnology, 54, pp. 70-75, DOI:10.1007/s13580-013-0089-8.

37. Huang X., Li J., Shang H., Meng X. (Effect of methyl jasmonate on the anthocyanin content and antioxidant activity of blueberries during, Journal of the science of food and agriculture, 95(2), pp. 337-343.

38. Kays S.J. (1991), Postharvest Physiology of Perishable Plant Products, An AVI Book, Van Nostrand Reinhold, New York. 
39. Turmanidze T., Gulua L., Jgenti M., Wicker L. (2017), Potential antioxidant retention and quality maintenance in raspberries and strawberries treated with calcium chloride and stored under refrigeration, Brazilian Journal of Food Technology Campinas, 20, e2016089.

40. Moyer R.A., Hummer K.E., Finn C.E., Frei B., Wrolstad R.E. (2002), Anthocyanins, Phenolics, and Antioxidant Capacity in Diverse Small Fruits: Vaccinium, Rubus, and Ribes, Journal of Agricultural and Food Chemistry, 50, pp. 519-525.

41. Burin V.M., Falcão L.D., Gonzaga L.V., Fett R., Rosier J.P., Marilde Terezinha Bordignon-Luiz M.T. (2010), Colour, phenolic content and antioxidant activity of grape juice, Food science and technology, 30(4), pp. 1027-1032,

42. Zhang J., Wang X., Yu O., Tang J., Gu X., Wan X., Fang C. (2011), Metabolic profiling of strawberry (Fragaria $\times$ ananassa Duch.) during fruit development and maturation, Journal of Experimental Botany, 62(3), pp. 1103-1118, DOI:10.1093/jxb/erq343 